\title{
Strategic Steps in the Sheep and Goat Branches
}

\author{
Andras Javor ${ }^{1}$ - Andras Nabradi ${ }^{2}$ \\ Sandor Kukovics $^{3}$ - Gyula Bekesi ${ }^{4}-$ \\ Peter Hajduk ${ }^{5}$ - Laszlo Safar ${ }^{5}$ - Zoltan Raki ${ }^{6}$ - \\ Sandor Bedo ${ }^{7}$ - Peter Poti ${ }^{7}$ - Andras Molnar ${ }^{3}$ - \\ Gyorgyi Molnar $^{1}$ - Tamas Szekelyhidi ${ }^{8}$ - \\ Istvan Szucs $^{2}$ - Maria Abraham ${ }^{3}$ \\ ${ }^{1}$ University of Debrecen, Centre of Agricultural Sciences, \\ Faculty of Agricultural Sciences, Debrecen \\ ${ }^{2}$ University of Debrecen, Centre of Agricultural Sciences, \\ Institute of Agricultural Economics and \\ Rural Development, Debrecen \\ ${ }^{3}$ Research Institute for Animal Breeding and \\ Feeding, Herceghalom \\ ${ }^{4}$ Sheep Product Council, Szikszó \\ ${ }^{5}$ Hungarian Association of Sheep Breeders, Budapest \\ ${ }^{6}$ Informatics and Research Institute of Agroeconomics, Budapest \\ ${ }^{7}$ Szent Istvan University, Animal Breeding Department, Gödöllő \\ ${ }^{8} \mathrm{ACDI} / \mathrm{VOCA}$, Budapest
}

health) whose financial effect is considerable.

\section{SUMMARY}

The balance of the sheep and goat branches can be summarised as follows:

If the increase in stock size, specific yields, genetic improvement and modernisation are not realised, several thousand shepherds will lose their jobs and possibilities to work, and their families will lose their only source of livelihood.

Several hundred hectares of grassland will become weedy and the costs of crop protection will increase in these regions. Pollen pollution, the number of allergic ailments and medical costs will increase, mentioning only the main disadvantages. Its financial requirement is nearly equal to the one required for development without any essential compensation or production.

In order to develop a competitive branch, a subsidisation of 10-20 billion HUF is needed until the accession of Hungary to the $E U$, depending on the scale and progressivity of development. The subsidisation and realisation of the strategic steps would result in:

- the establishment of a registered livestock with 1.5 million ewes, which would ensure better market position for the branch in the $E U(5 \%)$,

- the establishment of a competitive and marketable branch with a production value of 15-25 billion HUF, calculated using the present price level (after accession, the branch would be self-operating and profitable, with the 6-8 billion HUF/year normative subsidisation by the EU),

- the establishment of a genetic potential which would ensure our participation in profitable international breeding animal market, which provides extra profit,

- the establishment of a sheep husbandry with better genetic potential and phenotypic performance, producing a quality of international level,

- the maintenance of the workplace of more than 10.000 people (saving 3-5 billion HUF/year of the budget),

- the maintenance of the condition of growing areas of grasslands with their advantages (crop protection and public 


\section{IMPROVING OR COLLAPSING}

The sheep and goat branches are in as critical a situation as all the other Hungarian livestock branches. Even the government has realised that the branch of small ruminants is one necessary point to be developed and wishes to promote its development. This improvement is required in order to maintain the rural population and the condition of grasslands, whose total area is over 1 million hectares. The nonoverstocked EU market, as well as here at home, also represent a promising market possibility.

The possible methods and tasks for the development of the small ruminant's industry and an impact assessment of the application of EU council regulation 3031/89 are discussed in this study.

\section{EXTERNAL CONDITIONS}

Without familiarising one's self with developments in the various sheep and goat branches world-wide, neither the present status of our branch of small ruminants can be defined, nor can the future of the branch be predicted. Some regions are especially important for us: New Zealand, South America, the EU, Central and Eastern Europe.

In this study, we consider the following points:

1. Globally, one recognises a slight decrease in the stock number of sheep and goats used for breeding, although tendencies differ by region.

2. There are two ways to develop the branch of small ruminants. When choosing the appropriate way, environmental and financial conditions, as well as the human factor, have to be taken into consideration first.

Geographic regions with large grassland areas (China, New Zealand, Australia, South America) are trying to increase production by raising their stock numbers and maintaining a low level of production costs.

Another means of development increases production, winning greater profit margins, by improving unit indices or even by increasing production costs as well without any stock increase.

Specialisation has become an integral part of sheep breeding which is typical in the EU countries.

The sheep branch of those countries which did not choose between the two development models due to different reasons and taking into consideration the national conditions - started to collapse. Although the strength of this negative trend varies in each country, it is generally endemic in every Central and Eastern European country and in the countries of the former Soviet Union.

3. The average level of meat production in the sheep and goat branches in the world exceeds the national average considerably (20-25\%). Our divergence from the normal average production level of the EU is more than $8 \mathrm{~kg}$ in bony meat, which exceeds even $50 \%$. In milk production, in comparison with milk producing sheep farms only, our lag is several hundred percentages.

The level of wool production in Hungary, which lost its importance long ago, is outstandingly high, due to the extremely high ratio of merino.

4. True for all the sheep and goat branches in the world is that the majority of products is sent to the world market instead of the national markets. The meat market can be characterised by quota regulation, while wool and milk markets can be characterised by liberalisation.

The price level of meat and cheese is usually high, these products appear on good paying markets. Thus, high level markets are extremely sensitive to quality. In addition to quality, marketability, processing, packing, market and price flexibility are the most important aspects of the world market.

5. Even the branch of small ruminants was affected by general crises. As a result, prices decrease in spite of the slight increase in sheep and goat meat consumption. This disparity can only be explained by pointing to the increasing population of the world.

6. Our target market countries have better organised markets, better protect their producers, and their branch of small ruminants provides a safe income for producers. This can be explained primarily by the subsidisation system of the EU.

7. Among our Eastern European competitors, only Romania can be considered as strong a competitor as regards stock number or costs, among others.

\section{THE STATUS OF THE BRANCH OF SMALL RUMINANTS IN HUNGARY}

The most focal question is the required size and structure of the branch of small ruminants in the future. Our opinion is that this problem can be solved only through development, growth and improvement. The stock number has to be nearly doubled and the specific yields increased by $50 \%$. We must realise that a profitable and competitive sheep husbandry can only be developed by increasing the number of stock and through quality improvement before the accession of Hungary to the EU. If we are members, maintenance could be our sole aim, which would undermine our national interests, (subsidisation, environmental protection, economic reasons) considering the present situation. Thus, an increase in stock number and quality improvement could be the only possibilities for improvement. The reasons for this opinion, as well as the means of achieving both, will be outlined further.

Competitiveness of the sheep and goat branches 
may only be reached through an overall ,package” of steps. Solving only a few of the total problems will only provide recurrent or poor results, and will not contribute to developing the branch of small ruminants, which is in a catastrophic situation.

In order to develop this branch, the most essential step is to re-establish its profitability. Although increasing profitability can be considered as a partial task, its effects can be realised through other determinant factors, thus the process would be unanimously positive and irreversible. For this purpose, a subsidisation system should be applied which would provide the average Hungarian sheep and goat breeder with the possibility to reproduce on an increasing scale. Today, it is not enough to compensate their losses with an income which would ensure simple reproduction. Rather, the breeder should have the possibility to increase effectiveness by extending production, increasing his yields. Furthermore, the quality of produced goods should reach levels required by the EU.

The only purpose of the system applied in the EU at present is to make production profitable under both favourable and unfavourable conditions. This works against extension. The support system applied there, which is much higher than that of Hungary, thus cannot be applied alone to manage and develop our sheep breeding until accession. However, the subsidisation level, calculated on the basis of the EU countries, would be enough to solve the problems of the branch, with a modified structure.

The EU's subsidisation level would:

- ensure profitability of the branch,

- ensure relative safety of sale,

- provide equal chances for sheep farms operating under different conditions,

- provide possibility for extending production,

- reduce the fluctuation of producers' prices.

On the other hand:

- the improvement of genetic basis,

- the improvement of quality,

- the increase in the specific yields, indices,

- the modernisation of feeding, fodder management and grazing,

- the improvement of market image,

- the improvement in the qualification of shepherds,

- the increase in the ratio and level of processing,

- the increase in stock concentration,

- the modernisation of land ownership structure would not be realised automatically (although it would serve as a frame).
Thus, subsidisation should consist of several elements and should be task-oriented.

These are as follows:

- income compensating (normative) subsidisation,

- regional income compensating subsidisation (less favoured areas),

- production development, quality improvement of female breeding animals, stock increase,

- quality development, specialisation with special emphasis on male breeding animal management,

- solutions for market safety and recurrent income compensation,

- trade and marketing policy development,

- informatics development, modernisation of education and consultancy,

- modernisation of feeding, grassland and fodder management,

- processing and possibilities for improvement.

In order to effectively utilise subsidisation, consensus is needed from all the participants in the vertical integration in the branch. It is also necessary to determine the responsibilities and tasks necessary for the competitiveness of the branch.

Profitability growth does not mean that its allocation is satisfactory and that the income is utilised for the development of the branch. Thus, the system could be used until the accession of Hungary, but only if this would meet all the previously listed requirements. Although incompatible with the objectives towards reducing the jurisdiction of subsidisation, it has to be emphasised that the simplified system could be used effectively only in an existing producing, trading and consuming system. In our case, these objectives must also be built into the subsidisation system.

Taking into consideration all the abovementioned findings, the steps supporting the objectives and realising all the interests of the country must include the following elements, identifying the performers of the tasks and their source requirements.

\section{Income compensating subsidisation}

Hungarian sheep breeding, in its present form, reports a yearly loss of 1.3-1.4 billion HUF. This loss was the underlying reason behind the continuous reduction in stock number. The present number of ewes (8-900.000) is due to the specialities of the branch, namely with its ,loss-buffering” ability. However, this ability decreases in direct proportion to the development of economy.

In order to make the branch of small ruminants attractive for the participants in the vertical integration in the branch, an income of $10 \%$ proportional to costs must be provided. This means 1.3-1.4 billion HUF at the branch level. The sum of these two components is nearly $2.500 \mathrm{HUF} /$ ewe.

A possibility for controlling inputs must also be developed in parallel with the introduction of 
normative subsidisation. For this purpose, marking animals and the registration system used in the EU seems to be suitable, and even an independent organisation could perform these duties.

Income compensating subsidisation could be financed only from the budget and its introduction on the level explained above would, even now, be too late. Nevertheless, it should by no means be introduced later than 1999 or 2000.

Otherwise, a further decrease can be expected in the stock number, and the conditions of grasslands and the biological state of the environment will also further decrease. It has to be considered that with the liquidation of some sheep farms, the number of unemployed shepherds would increase, as will the budget liabilities, reaching and exceeding the level of normative subsidisation explained previously. This amounts to 300-400.000 HUF/shepherd, without any essential compensation. If the branch were liquidated, this amount would be several billion HUF/year.

Thus, it is proved that the preservation of the branch of small ruminants is necessary for the government because of the following main reasons: employment policy, environmental protection, structural and social respects.

\section{Regional income compensating subsidisation (less favoured areas)}

In Hungary, just as all over the world, less favoured areas are utilised with small ruminants. In these areas, farmers and employees have few employment alternatives. The environment has to be maintained, and the condition of even these areas preserved. This is why it is important to help those enterprises to operate economically which are trying to assist with the national goals of job-site establishment, utilisation and maintenance of lands. The EU also realised this, and provides producers in these areas with compensatory subsidisation. The share of this expenditure in the budget depends on the percentage of sheep and goat stock living in such areas. In Hungary, approximately $66.7 \%$ of the ewe stock lives in less favoured areas of which $40.6 \%$ lives in cumulatively less favoured areas. According to our calculations, the source requirement is about 1.0 billion HUF. Therefore, it would be reasonable to introduce this subsidisation right now.

In many cases, regional classification of the headquarters of farm businesses and the location of the actual farms are different. This problem has to be solved by the time of accession.

If the regional income compensating subsidisation for less favoured areas is not introduced in time, 2-3.000 shepherds will apply for unemployment benefits. These people work in those areas where small ruminants have no alternative and they could not be retrained successfully. The unemployment benefit paid from the budget would be $0.8-1.0$ billion HUF/year, which is nearly equal to the suggested reasonable amount of income compensating subsidisation for less favoured areas.

\section{Production development, quality improvement of female breeding animals, stock increase}

If the subsidisation for stock increase was combined with other types of subsidisation and was not aim-oriented, it would be difficult to expect from the branch struggling with lack of sources and income that it reinvest its income immediately into extended production.

The amount of subsidisation for income compensating development depends basically on the required stock size and progression of stock development. The number of female breeding animals required in Hungary numbers 1.5 million. However, it must be emphasised that this stock increase cannot be solved with the existing national stock.

Any kind of import in order to reach the required stock number of 1.5 million female animals could be acceptable:

- it would not interfere with Hungarian breeding aims (which differ from the individual aims of breeders),

- pre-financing, controlling and ensuring continuous utilisation for breeding purposes and preserving the genetic value of the imported stock were assured by the state.

According to our calculations, this development has to be realised within 3 years, with a subsidisation of 1.5 billion HUF.

Our calculations concerning this strategic plan were submitted to the Minister of Agriculture by December 1996. In this plan, we explained that farms for keeping import breeding stock and interventional farms were needed, in order to improve the importance of the pre-financed (from the budget) import and subsidised valuable breeding stock, increasing the profitability of Hungarian sheep and goat farms. In the import arrangement and the further breeding tasks, the state or its responsible organisation has to play an essential role. This could be solved using a newly developed organisation or a strengthened, existing organisation.

The source requirement of the budget is 1.5 billion HUF/year, which will be increased periodically with credits and interests because of prefinancing. (The detailed calculation is available in the above-mentioned material.) Sheep farms will contribute to the development with nearly the same amount, 1.5 billion HUF. The increasing stock number and profitable sheep farms will result in higher employment rate, better environmental protection and also in higher payments of taxes for development, if they can do so after re-establishing profitability.

Determining the ratio of varieties is a considerably complex question. In spite of the several advantages of merino, with this variety the long-term chances regarding quality and level of production cannot be assured. Merino is not effective enough 
under intensive conditions and cannot be kept under extensive conditions without any production loss.

\section{Quality development, specialisation with special emphasis on male breeding animal management}

The quickest and most effective way to change the ratio of varieties to improve the variety supply of male animals. In the breeding structure, which consists of three steps, high level, pure-bred breeding farms are required.

On the highest level, where male animals are bred, the number of available stock in each genotype has to be increased. It has also to be taken into account that without continuous import, the genetic and phenotypic improvement, required in each variety will be narrowed down. Thus, if we want to breed, we have to develop and maintain a population of several thousand animals. We could thus reach breeding and market positions in Central and Eastern Europe, as well as some extra profit for the branch. Our breeders would no longer depend on EU breeders.

On the second level, in breeding stocks, merino will be the most important variety until the diffusion of specialised and genetically consolidated genotypes. Unfortunately, their development, due to the late start (although specialisation was announced in 1982), will take several years. However, most of the possible genotypes are well known to Hungarian breeders.

On the third level, in producing stocks, we are allowed to produce only with crossed populations. For this purpose, dairy and meat-type genotypes can be used.

On all the three levels of production, the special yields have to be increased, even through the specialisation of production. 1.5-1.6 utilised lamb/ewe and/or 1501 milk can be considered as an internationally acceptable competitive level. Sheep farms established with the purpose of environmental protection can be excepted, although higher yields would be desirable even there. Their ratio is $20-40 \%$ in Hungary.

The genetic potential of the national sheep stocktaking into consideration the development realised during the last 30 years - is not suitable alone to develop a competitive sheep branch even if we do not plan a considerable increase in the stock number. This is particularly true should improvement be combined with a considerable increase in stock number.

Within this development, the role of sheep farms with professionally, well-equipped leaders will be fundamental. However, should these want to assure their share in the breeding tasks, they have to recognise their long-term interests. For this reason, the role of the Committee for Hungarian Sheep Breeding will be essential.

The role of the state, in addition to maintaining the free choice of varieties, should be determinant in increasing male animal supply and their accessibility from the side of producers. The supply should consist of 20-25 genotypes, ensuring specialisation and high level production. According to our calculations, specialisation for milk production could provide a solution which could extremely change the profitability of sheep husbandry.

Until the real breeding animal market is established, the work of breeding farms and their market conditions have to be supported. For this purpose, the most suitable means is so-called male animal subsidisation. If the price of two fattened animals (25.000 HUF) and a classified breeding animal would be equal (the difference would be covered by the budget) a ,male animal law" could easily be introduced and the quality and quantity indices could also be improved quickly.

However, this system would require detailed planning prior to any guaranteed state procurement. The male animal demand has to be reported in 1998, in order to utilise the male animals originating from planned production in 2000 .

It has to be taken into account that the available time is quite short, thus the ratio of import male animals could be disproportionately increased for several years due to genotype supply and demand, which could be effectively utilised.

The source requirement, since production would be pre-financed by the breeding farms, will only be high in 2000 or 2001 . This sum is expected to reach 0.50-0.75 billion HUF, calculated with the prices of 1998, and this level should be maintained for 2-3 years.

\section{Solutions for market safety and recurrent income compensation}

The branch's sale problems are traceable to several flaws, the most important being:

- only one market is available,

- organised production is lacking,

- low level of marketing,

- simple supply,

- poor branch adaptability.

If income were considerable in the branch, it would be able to compensate the problem itself? Since income is low, the most suitable means would be establishing and maintaining the interventional fund. This could only be realised in the case, when 3$5 \%$ of the return from sales could be used for this purpose, which would only be true with profitable production. This would amount to 0.4-0.6 billion HUF on the branch level, which could not be withdrawn from the branch even through reallocation.

Until the profitability of the branch allows, the intervention fund has to be covered from the budget.

If the level of profitability were to reach the required level, the central intervention could be blocked, since the branch would be able to solve crisis problems and heal itself.

Until that time, it would be required to provide 0.5 billion HUF from the budget for this purpose 
from the next year. Other possibilities affecting market conditions will be explained in other areas.

\section{Trade and marketing policy development}

Possibilities for trade development of national sheep breeding seem to be limited in respects of live animal and meat. This situation originates from the past. Companies developed from the former monopoly export company did not considerably change their trading partners. If there was any change, it was in the reduction in the number of „target countries" or partners. This predetermined the present situation: defencelessness and incompetence.

The reduced quantity and poorer quality of products and the less favourable market positions for carcasses worsened the situation. It was also unfavourable for us that our slaughterhouses went into Italian ownership.

Our foreign trade policy should be totally reorganised. In addition to maintaining our old markets and refreshing some others, new markets must also be acquired. If the composition, quality and processing levels of products have to be changed for this purpose, the necessary conditions have to be provided.

The „Guaranteed Quality Hungarian Lamb” title has to be introduced in any case, which would be awarded by an independent qualifying organisation. Quality improvement could be solved in this case if aim-oriented subsidisation would also promote it. Utilisation of the normative subsidisation would be more effective if its payment depended on the sale of quality lamb.

More emphasis has to be laid on advertisement activities and promotion, among many other things.

The problems are the same as regards wool and dairy products, although they do not affect basically the effectiveness of the branch, due to their small ratio.

The most important reserves of the branch are the unutilised capacities of national consumption. Today, meat consumption is $0.3-0.4 \mathrm{~kg} /$ capita, and $4-5 \mathrm{~g}$ per capita for sheep and goat cheese. Wool consumption is significant in comparison with developed nations. This can only partly be explained by the lower income of Hungarian consumers. The most common reasons are the poor quality of supply, consumer habit and very poor trade and marketing practice. The result is the following: Hungarian consumers do not know or look for sheep and goat products. An increase in national consumption would improve and ensure sales and market balance. A stronger national market background would be important in processing.

Increasing the importance of sheep and goat products both in the export and national consumption markets is the role of merchants. Thus, providing financial sources would also be in their interest. Unfortunately, only a moderate part of their income was reinvested in the development of the branch, although such investments would have been extremely important, especially for the development of trade and marketing activities.

In addition to improving the level of processing, quality also has to be improved. Paralelly, the introduction of quality assurance activities has to be promoted in the branch. It would be reasonable to link these activities to normative subsidisation practices in the long run because, in this case the application of quality assurance in the sheep and goat branches would be accelerated, and technological disciplines would be more rigorously monitored which is a required basis for quality production. If realised, the fluctuation in the quality of products will decrease.

In addition, the branch should receive funding from the AMC budget on the basis of its economic importance. This should be 30 million HUF/year, figuring in the ratio of export, economic importance of the branch and planned tasks.

\section{Database development, modernisation of education and consultancy}

Marking of animals has already been tried. Since the registration of animals did not have advantages, many shepherds were against it. If the subsidisation system is developed on the basis of the previously mentioned findings and facts, and the government is willing to do so, the demand for registration will increase and the task made easier.

Our information on the stock number in the sheep branch originates from the database of the Council for Production, which can be accepted with a margin of error of $10 \%$.

The lack of necessary capital to solve and properly monitor the task is the main problem. The problems are the same as in the case of any other problem-solving task: although something is being done to fulfill the task, the available resources are not enough to ensure high quality solutions and monitoring, which is why we have to calculate with a higher margin of error.

By duplicating the present amount of subsidisation for database modernisation (20 million HUF), these problems could be solved. The law obligates of the Minister of Agriculture and Rural Development to provide the necessary sources.

An intolerable situation is that shepherd training practically does not exist in Hungary. Shepherds must learn professional skills from each other, but one of the reasons for low production levels is the lack in properly qualified shepherds. This is evident not only in their practical knowledge, but also in their attitudes. Only one piece of data is enough to support this claim: More than 600 horse breeders were trained during the last 5 years, while the number of trained shepherds numbered a dismal 3.

\section{Modernisation of feeding, grassland and fodder management}

The practice that the production of animals has to be reduced to the yield of the environment and grassland must not be followed. It is a basic principle 
and must be emphasised because the modernisation and improvement of our grasslands has not been carried out. If we want to feed our animals only on grasslands, we have to consider that competitive yields cannot be reached even with merino or any other specialised variety.

The breeding of small ruminants can be envisioned on three levels. Breeding would be profitoriented under the best conditions, subsidised under average conditions and financed in the less favoured areas.

It is another important professional mistake in sheep and goat feeding, that from each kind of fodder, those of poorest quality are used. The required yield (1.5 lamb/year/ewe; 100-150 $1 \mathrm{milk}$ ) can be reached only by feeding healthy and good quality fodder.

The yield of grasslands can be utilised only on fenced and cultivated grasslands where the natural life of sheep is unrestricted. More importantly than fencing and cultivating grasslands, property has to be protected by law. The willingness to invest in and cultivate grasslands is limited by the fact that most of these areas are not owned by shepherds, thus they are not interested in their improvement. Unfavourable contractual conditions intensify the shepherds' indifference.

On those grasslands where intensive sheep husbandry cannot be carried out economically even by fencing in the area, producers have to be provided with higher subsidisation, due to the previously explained reasons. These areas (even in spite of the losses) can be the most effectively utilised by sheep or goat. Efforts have to be made towards unifying the ownership of buildings, grasslands and livestock, because effective production and its regulation can be assured the most effectively only in this way.

The ratio of fodder producing lands owned by shepherds will probably not increase, which differs from EU practice. This increases the costs of production and also the importance of maintaining the quality and value of bulk fodder.

In Hungary, sheltered stack-yards and stable, sheltered silos for protecting the quality of fodder can be found only on a few sheep farms. This is due to a lack of professional knowledge. The level of investment in the branch is low which also ranks among the reasons.

By increasing the innovative ability of shepherds, considering continuous investment supports, the quality of fodder could be considerably improved.

The role of sheep farms must to be reevaluated as regards stubble-field and by-product utilisation. The use of stubble-fields as fodder resources for sheep is practically non-existant, since other producers own these fields. In spite of this fact, this fodder, as a complementary source of fodder, should also be utilised, since its biological advantages are proved in spite of the occurring problems.

By-product utilisation is unanimously an economical question. Because of its low nutritive value, it can be offered only in those cases when the related costs are low (i.e. transportation or storage).
In some areas, $5-10 \%$ of the annual fodder demand can be met by using by-products, which is a considerable ratio.

Task summary:

- new methods and results of feeding have to be introduced quicker into sheep and goat husbandry,

- cost-optimisation instead of cost-minimisation in fodder management,

- to promote investments to preserve the quality of hay and fermented fodder, professional improvement,

- to promote the use of concentrates instead of corn fodder,

- modernisation of grassland management, which should be based on long-term contracts or joint ownership.

Solving the questions of property protection to ensure safe animal husbandry is beyond the abilities of agricultural leadership.

\section{Processing and possibilities for improvement}

Hungarian sheep foreign trade has sold traditional products on the foreign market for decades. Our main export items (without considerable changes) are live lamb, cheese (kaskhaval) and fatty wool (not as old long as the previous ones).

Unfortunately, the changes which occurred during the last few years were not favourable for Hungarian sheep breeding. Among the competing countries, some have larger quotas (Romania), some increasingly meet the consumers' demand better (eg. New Zealand) and some produce cheaper and better quality even than our lambs, using our own technology (eg. Spain). The subsidisation system of the European Union countries guarantees the income of sheep breeders (price of product + subsidisation). Thus, the risk for producers in the EU is reduced to zero.

The situation is similar in the case of milk production. The quality of final products, which are produced from relatively poor quality milk, results bad market position. Competing countries offer the same quality cheese (same type) much cheaper (Romanian, Slovakian and Bulgarian traders).

The sale of wool does not have any considerable effect on the branch, since it has no position on the market. The achievements of Hungarian processors working with small volumes prove that the value of wool can be multiplied by processing.

Logistical conditions of meat and live animal trade are unfavourable due to the continuous hygienic dangers of transport. It worsens the situation that the safety of transportation routes cannot be considered absolutely safe, although the situation has improved.

Due to social protest for the protection of animals, the obligations and expenditures of transporters will increase in the near future - resting, feeding, establishment of parking stations - and their activity is expected to be stopped in the long run. 
Thus, it would be really practical to step forward now in the field of marketing and to look for new markets. In the long run, management in a branch showing deficit is difficult to imagine without central will. It worsens the situation that slaughtering capacities with EU licence do not belong to Hungarian owners. Thus the basis of husbandry is totally missing at present.

The Council for Production should study the potential national slaughtering capacities, which are suitable for slaughtering sheep, as well. Even their related recording could increase the safety of Hungarian producers.

Cheese producers and tradesmen are in a favourable position now, since these products can be sold easily, also due to the small quantity. At the same time, it is a real danger that our Eastern competitors can push us out of traditional markets with their lower prices since the market for kaskhaval is quite small. It would be desirable to look for markets or develop such products which could afford the real, higher price of raw material.

As regards wool products, the development of handicraft could be imagined under the present economic situation and there is a legal possibility as well for the extension of central purchasing wool products.

\section{Concentration of livestock}

The development of the branch structure was unfavourable in the last few years in Hungary. As the large and medium sized stocks frittered away, the quality of products, competitiveness, labourefficiency, and the number of technological variants decreased, but the ratio of unqualified workers and illegal male animal utilisation increased. At the same time, the number of animals kept in sheds in inhabited areas has increased.

By emphasising the importance of part-time farms, it has to be stated that neither breeding and production strategies, nor complex branch level management, can be based on them.

On an effective farm where frequent lambing can be effectively realised, labour is exploited, male animal utilisation is economical, and investments into machinery are affordable, the number of ewes is higher than 300-400, depending on their utilisation. This stock size could cover the living expenses of a family in the case of appropriate yields.

Since the resource requirement of a sheep farm establishment with 300 ewes is quite high (10-12 million HUF), it cannot be expected from anyone to embark on it from zero without any professional and financial background. Thus, farmers owning livestocks with more than 100 animals should be the target group for developmental subsidisation. Although their number is quite different by county, their number averages nearly 1.500 at the country level. Their appropriate subsidisation would lead to an increase of $20 \%$ with the best efficiency.

This solution does not require another type of subsidisation since, on the basis of the other

suggested sources, (labelling these money) the problem could be solved. It must be emphatically stressed that family farms are, however, the most sensitive to economic, financial difficulties.

\section{REFERENCES}

Bekesi, Gy.-Hajduk, P.-Javor, A.-Thuroczy, Z. (1994): Juhtenyésztésünk helyzete, a piaci lehetöségek. Magyar Juhászat. A Magyar Mezőgazdaság melléklete, 3. 3. 3-7.

Berenyi, A. (1998): Az EU Marha-, Juh- és Kecskehús Közös Piaci Szervezete. FVM kiadvány, Budapest

Fesus, L. (1998): A juhtenyésztés helyzete és versenyképessége. Állattenyésztés és Takarmányozás, Juhtenyésztési különszám, 47. 41-46.

Guba, M.-Janowszky, Zs.-Raki, Z. (2000): A magyar juhászat hatékonyság-növelési esélyei és a szabályozás EU-konform továbbfejlesztése. Agrárgazdasági tanulmányok, 4. 137.

Herold, I.-Javor, A. (1984): A juh takarmányozása. Mezőgazdasági Kiadó, Budapest, 141.

Javor, A. (1993): Mi jellemzi a magyar juhtenyésztést? Magyar Juhászat. A Magyar Mezőgazdaság melléklete, 2. 5. 4-6.

Javor, A. (1996): A juh és jövedelme. Magyar Juhászat. A Magyar Mezőgazdaság melléklete, 5. 2. 7-8.

Javor, A. (1996): Juhhizlalás: mibe kerül? Magyar Juhászat. A Magyar Mezőgazdaság melléklete, 5. 4. 5.

Javor, A. (1997): Mélyrepülés, vagy válság? Magyar Juhászat. A Magyar Mezögazdaság melléklete, 6. 6. 2-3.

Javor, A. (1998): A juhászat minőségorientált menedzsmentje. „AGRO-21” Füzetek. Az Agrárgazdaság Jövőképe, 21. 87102.
Javor, A. (2000): Indukált gondolatok. Magyar Juhászat + Kecsketenyésztés. A Magyar Mezőgazdaság melléklete, 9. 8. 4-5.

Javor, A.-Bekesi, Gy.-Kukovics, S.-Molnar, Gy.-Koleszar, T. (1997): A hazai juhállomány jellemző adatai. Magyar Juhászat. A Magyar Mezögazdaság melléklete, 6. 2. 4.

Javor, A.-Molnar, Gy. (1997): A juhok vágása, minősítése és minősége. (In: Juhászati technológia, szaporodásbiológia, ökonómia, Szerk.: Szabone Willin, E.) Gyöngyös, 108-112.

Javor, A.-Molnar, Gy.-Bekesi, Gy.-Nabradi, A.-Molnar, M. (1997): Juhágazat és jövedelem. Magyar Juhászat + Kecsketenyésztés. A Magyar Mezőgazdaság melléklete, 6. 5. $2-4$.

Javor, A.-Nabradi, A. (1999): A fajtaválasztás szakmai és gazdasági megfontolásai. (In: Tenyésztési- és Fajtahasználati Útmutató, Szerk.: Javor, A.-Fesus, L.) Debrecen - Szikszó Herceghalom, 129-134.

Javor, A.-Nabradi, A. (1999): A juhágazat szerkezete és hatása az árukibocsátásra. ÁTK Szaktanácsadási füzetek, 44-55.

Javor, A.-Nabradi, A. (1999): Állománykoncentráció a juhágazatban és annak hatása a gazdálkodásra. Magyar Juhászat + Kecsketenyésztés. A Magyar Mezőgazdaság melléklete, 8. 10. 6-7.

Javor, A.-Nabradi, A.-Fenyvessy, J.-Molnar, Gy.-Arnyasi, M.- 
Varszegi, Zs. (1998): A juhtermékek minősége és a versenyképesség. XXI. Georgikon Napok, Keszthely, A versenyképes magyar agrárgazdaság az évezred küszöbén. III. Állattenyésztés, 84-88.

Javor，A.-Nabradi, A.-Fenyvessy, J.-Molnar, Gy.-Arnyasi, M.Varszegi, Zs. (1998): A versenyképes minőség. Magyar Juhászat + Kecsketenyésztés. A Magyar Mezőgazdaság melléklete, 7. 8. 6-7.

Javor, A.-Nabradi, A.-Madai, H.-Varszegi, Zs.-Arnyasi, M.Molnar, Gy. (1998): Piac- és árérzékenység a juhászatban. Magyar Juhászat + Kecsketenyésztés. A Magyar Mezögazdaság melléklete, 7. 7. 3-4.

Komlosi, I. (1998): Tenyésztési tartalékok más szemmel. Állattenyésztés és Takarmányozás, Juhtenyésztési különszám, 47. 225-229.

Kukovics, S. (2000): A tej- és hústermelés alternatívái a juhtenyésztésben. Magyar Juhászat + Kecsketenyésztés. A Magyar Mezögazdaság melléklete, 9. 5. 4-5.

Kukovics, S.-Javor, A.-Molnar, Gy.-Abraham, M.-Molnar, A. (1997): A juhtenyésztés minőségének fejlesztése. „AGRO-21” Füzetek. Az Agrárgazdaság jövőképe. Stratégiai kutatási programok az agrárgazdaság minőségi dimenziói, 17. 76-100.

Lengyel, A.-Toldi, Gy.-Mezoszentgyorgyi, D. (1998): Genetikai tartalékok a juhok hústermelésében. Állattenyésztés és Takarmányozás, Juhtenyésztési különszám, 47. 125-133.

Lengyel，L.-Nagy，Z.-Toth，I. (1998): Veszteségcsökkentés a juhágazatban. Magyar Juhászat. A Magyar Mezőgazdaság melléklete, 7. 4. 8-9.

Lovas, L.-Hancz, Cs. (1998): A teljesítményvizsgálatok korszerűsítésének szükségessége és lehetőségei, különös tekintettel a gyapjútermelésre. Állattenyésztés és Takarmányozás, Juhtenyésztési különszám, 47. 149-158.

Molnar, Gy. (1999): A magyarországi hízóbárány vágás utáni minősítése. Doktori (PhD) értekezés, 150.

Molnar, Gy.-Varszegi, Zs.-Arnyasi， M.-Javor, A. (1999): A bárány, mint végtermék. (In: Tenyésztési- és Fajtahasználati Útmutató, Szerk.: Javor, A.-Fesus, L.) Debrecen - Szikszó Herceghalom, 107-128.

Mucsi, I. (1998): Szaporodásbiológiai tartalékok a juhágazatban. Állattenyésztés és Takarmányozás, Juhtenyésztési különszám, 47. $135-140$

Nabradi, A.-Javor, A.-Kukovics, S. (1997): A magyar juhtenyésztés gazdasági tartalékai. Magyar Juhászat + Kecsketenyésztés. A Magyar Mezőgazdaság melléklete, 6. 112. 4-6.

Nabradi, A.-Javor, A.-Kukovics, S.-Bekesi, Gy.-Hajduk, P.-Safar, L.-Raki， Z.-Bedo， S.-Poti， P.-Molnar， A.-Molnar， Gy.Szekelyhidi, T.-Szucs, I.-Abraham M. (1999): Az EC 3031/89-es rendelet alkalmazásának hatása a juh- és kecskeágazatra. PHARE tanulmány, 1-120.

Sarosi, I.-Javor, A. (2000): Vitafórum a juhágazat helyzetéről és jövőjéről. Magyar Juhászat + Kecsketenyésztés. A Magyar Mezögazdaság melléklete, 9. 8. 6-9.

Selley, E. (2000): A vágóbárány paci helyzete. Magyar Juhászat + Kecsketenyésztés. A Magyar Mezőgazdaság melléklete, 9. 9. 4-5.

Varszegi, Zs. (1999): Magyarországi genotípusok vágási százalékának és EUROP minőségének összehasonlító elemzése. Állattenyésztés és Takarmányozás, 48. 6. 736-737.

Varszegi, Zs. (1999): Romániai import bárányok minősége és a minősités gyakorlata. V. Ifjúsági Tudományos Fórum, PATE, 218-221.

Veress, L.-Bedo, S.-Lovas, L.-Mucsi, I.-Lengyel, A.-Zomborszky,
Z. (1995): Juhtenyésztés. (In: Állattenyésztés 1. Szerk.: Horn, P.) Mezőgazda Kiadó, Budapest, 305-444.

Veress, L.-Javor, A. (1990): A juh tenyésztése és tartása. Egyetemi jegyzet, Debrecen, 198.

OMMI Juhfajták vizsgálata, 1999 